\title{
Management of municipal solid wastes and production of liquid biofertilizer through vermic activity of epigeic earthworm Eisenia fetida
}

\author{
Kanchan Mishra $\cdot$ Keshav Singh $\cdot$ C. P. Mani Tripathi
}

Received: 11 September 2013/ Accepted: 16 March 2014/Published online: 26 June 2014

(C) The Author(s) 2014. This article is published with open access at Springerlink.com

\begin{abstract}
Background Animal and municipal solid wastes (MSW) create environmental pollution. It is one of the most challenging problems which require attention. Efforts were made for the conversion and eco-management of animal and municipal wastes into safe and hygienic products by an epigeic earthworm Eisenia fetida. The excess use of chemical fertilizer and synthetic pesticide has changed the texture of soil and its fertility.

Result The chemical analysis of different combinations of MSW and animal wastes before and after vermicomposting showed, that there was significant decrease in total organic carbon, $\mathrm{C} / \mathrm{N}$ ratio and $\mathrm{pH}$ in the final vermiwash. The significant increase in the level of total Kjeldahl nitrogen, total potassium, total phosphorus and total calcium was observed after vermicomposting in all the prepared combinations of MSW with different animal dungs. Conclusion It was recorded that due to the vermic activity, the MSW and animal wastes get changed into nutrient rich, ecofriendly, and biofertilizer. The observations reveal that by vermicomposting not only ecofriendly management of MSW can be achieved but also potent vermiwash can be made which are helpful in increasing the production of crops.
\end{abstract}

Keywords Municipal solid wastes - Eisenia fetida . Eco-management $\cdot$ Chemical fertilizer $\cdot$ Vermiwash

K. Mishra · K. Singh · C. P. M. Tripathi $(\bowtie)$

Department of Zoology, DDU Gorakhpur University,

Gorakhpur, India

e-mail: chandra_tripathi2001@yahoo.com

\section{Introduction}

Almost all developing countries have major problem for overpopulation and its generated wastes (Kaviraj and Sharma 2003). Management of municipal solid wastes (MSW) which are produced in metropolitan cities is great challenge in the absence of proper technology for elimination and processing of these biowastes. Record production of MSW in New Delhi was $136 \mathrm{~kg} /$ person/year (Bhartiya and Singh 2012). In India, mostly urban areas generated 25 million ton solid wastes annually (Aalok et al. 2008) which contain 50-60 \% compostable material. Garg et al. (2005) reported that million of ton live stock excreta are produced annually. An estimation done in USA showed that the MSW produced i.e., 236 million tones was $50 \%$ more than that produced in 1980 . Since these wastes were highly organic in nature including batteries, paint residue, ash, treated wood, electronic wastes, live stock excreta and industrial sludge were stern problem for the human health and environment (Bhartiya and Singh 2012) and noxious problem of MSW reported by many workers (Kaviraj and Sharma 2003). Animal, agro and kitchen wastes have odor and pollution problems (Garg et al. 2006), although these wastes were nutrient deficient for plant, containing $50 \%$ bio-carbon which feed by soil processors and converted into nutrient rich potent vermiwash to plant (Rouse et al. 2008). To overcome this problem by safe and hygienic method involving vermicomposting (Kaviraj and Sharma 2003). Although degradation of biowastes by microbes is natural phenomenon, earthworms are important drivers for this process (Aira et al. 2002). Management of organic wastes required an epigeic species, which have short life cycle, with small size and high rate of reproduction (Nath and Singh 2009; Chauhan and Singh 2012a). An epigeic form of earthworm increases the composting process to a significant level and produced better vermicompost. Eisenia fetida is an epigeic earthworm which 
plays an important role in transition of surface litter into inner layer of soil. E. fetida is successfully utilized for conversion of organic wastes into valuable product i.e., vermicompost (Nath and Singh 2009; Chauhan and Singh 2012a). The principle of vermicomposting involving the feeding processes of earthworm increases the surface area for microbial activity (Garg and Kaushik 2003). In the modern trend, verminculturist produced liquid extract of vermicompost that contains macro and micronutrients called vermiwash. Vermiwash enriched with plant growth hormones, enzymes, vitamins, increases growth rate, high productivity and resistance against various diseases for plant (Nath and Singh 2009). Vermiwash extracted from MSW contains high amount of organic matter, plant nutrients and soluble salt. After use of these vermiwash in soil increases carbon content, cation exchange capacity, nutrient content, soil bulk density and water holding capacity (Astaraei and Ivani 2008).

Since different animal dungs have variability in their chemical constituent, so the hypothesis of these studies was to find out the best combination of animal dung with MSW for obtaining vermiwash as well as the management of MSW with suitable combination of animal dung and also determined the chemical compositions of the vermiwash of different vermibed before and after vermicomposting. The future planning of our research work is to determine the effect on growth, flowering and development of different crops using the potent vermiwash.

\section{Materials and methods}

\section{Collection of wastes}

MSW were collected from the local municipality. Animal wastes viz. cow, buffalo, and horse and goat dung were collected from different farm houses of Gorakhpur city. MSW and different animal dungs (cow, buffalo, goat, and horse dung) were sprayed in layer of about 1-2 ft. and also exposed to the sunlight from 5 to 10 days for removing the various harmful organism and noxious gases.

\section{Collection of earthworm}

Earthworm E. fetida used for experiment was obtained from Vermiculture Research Centre, Department of Zoology, D. D. U. Gorakhpur University, (U.P.) India.

Experiment set-up and vermicompost production

Vermibeds of cow, buffalo, goat and horse dung with MSW in different ratios were prepared on the cemented earth surface. The seventeen vermibeds were formed in different ratios $(1: 1,1: 2,2: 1)$ of MSW with different aforesaid animal dungs. The size of each vermibed was $(30 \mathrm{~cm} \times 30 \mathrm{~cm} \times 10 \mathrm{~cm})$. Thus, formed vermibeds were moistened daily and incubated 50 adult individual of $E$. fetida placed in each vermibed. They were covered with jute pockets and moisten daily up to 40-50 days for maintaining the moisture (50-60\% RH). After 1-week interval, vermibed was turned manually. After 50-60 days, tea-like granular vermicompost appears on the upper surface of vermibed (Nath and Singh 2009).

\section{Extraction of vermiwash}

Vermiwash was extracted from different vermibeds of different combinations of animal and MSW in different ratios $(1: 1,1: 2,2: 1)$ by the help of vermiwash collecting device. The apparatus is made from plastic drum having capacity of two liter and a tap at the bottom. The drum is filled with broken bricks, about $3 \mathrm{~cm}$ thickened which is followed by sand layer of $2-3 \mathrm{~cm}$ thickness lastly filled with vermicompost with heavy population of earthworm, E. fetida; simultaneously, fresh water was added into the drum and a container kept below the tap of drum. The watery extract of vermicomposts, vermiwash was drained out of the drum (Nath and Singh 2009).

\section{Chemical analysis}

The $\mathrm{pH}$ was determined using a double distilled water suspension of each waste in the ratio of 1:10 (w/v) that has been agitated mechanically for $30 \mathrm{~min}$ and filtered through Whatman No. 1 filter paper. Total organic carbon (TOC) was measured by the method of Nelson and Sommers (1982). Total Kjeldahl nitrogen (TKN) was determined after digesting the sample with conc. $\mathrm{H}_{2} \mathrm{SO}_{4}$ and $\mathrm{HClO}_{4}$. (9:1 v/v) according to the method of Bremner and Mulvaney (1982). Total phosphorus (TP) was analyzed using the colorimetric method with molybdenum in sulfuric acid (Garg et al. 2005). Total potassium (TK) wasdetermined after digesting the sample in diacidic mixture (conc. $\mathrm{HNO}_{3}$ : conc. $\mathrm{HClO}_{4}=4: 1$, v/v), by flame photometer (Elica, CL 22 D, Hyderabad, India).

Statistical analysis

All experiments were replicated six times. Significant variance $(p<0.05)$ determined by two-way analysis of variance (ANOVA) was applied in between the different parameters of initial feed mixture and final vermiwash.

\section{Results}

The vermiwash of the final vermicompost showed significant change in different physico-chemical parameters, when 
different types of animal dung (cow, goat, buffalo, horse) were combined with municipal solid waste separately with respect to initial feed mixture by the use of epigeic earthworm E. fetida (Table 1; Figs. 1, 2, 3). Significant decrease in the levels of TOC, $\mathrm{C} / \mathrm{N}$ ratio and $\mathrm{pH}$ was observed in these combinations. However, the TKN, TP, TK, and TCa increase significantly in final vermicompost of all the combinations of animal dung with MSW. The maximum $68 \%$ significant decrease in the level of TOC in the combination of horse dung + MSW in 1:2 ratio (Fig. 1) and the $\mathrm{C} / \mathrm{N}$ ratio in the combination of cow dung + MSW (1:1 ratio) at level of $10.4 \pm 0.10$ were noted (Fig. 2). It was further recorded that the level of $\mathrm{pH}$ is shifted from neutral to slight basic in vermiwash obtained from all the combinations. The maximum decrease in $\mathrm{pH}$ level was noted in the combination of buffalo dung + MSW in 1:1 ratio (Table 1). The maximum

Table 1 Physico-chemical parameters of different combinations of animal dung with municipal solid wastes in initial feed mixture and final vermicompost

\begin{tabular}{|c|c|c|c|c|c|c|c|}
\hline Combinations & TOC $(\mathrm{g} / \mathrm{kg})$ & TKN (g/kg) & $\mathrm{C} / \mathrm{N}$ ratio & $\mathrm{TK}(\mathrm{g} / \mathrm{kg})$ & $\mathrm{TP}(\mathrm{g} / \mathrm{kg})$ & $\mathrm{pH}$ & $\mathrm{TCa}(\mathrm{g} / \mathrm{kg})$ \\
\hline \multicolumn{8}{|l|}{ Initial feed mixture } \\
\hline MSW (control) & $399.1 \pm 1.16$ & $5.83 \pm 0.17$ & $67.0 \pm 0.34$ & $5.61 \pm 0.15$ & $4.90 \pm 0.19$ & $6.97 \pm 0.19$ & $1.48 \pm 0.15$ \\
\hline Cow dung (control) & $483.1 \pm 1.16$ & $6.45 \pm 0.12$ & $74.0 \pm 0.37$ & $5.15 \pm 0.13$ & $4.20 \pm 0.17$ & $7.31 \pm 0.13$ & $1.56 \pm 0.13$ \\
\hline Cow dung + MSW (1:1) & $499.7 \pm 1.45$ & $14.2 \pm 0.23$ & $34.7 \pm 0.35$ & $7.35 \pm 0.17$ & $5.18 \pm 0.11$ & $7.45 \pm 0.14$ & $2.20 \pm 0.17$ \\
\hline Cow dung + MSW (1:2) & $641.2 \pm 1.24$ & $9.40 \pm 0.15$ & $68.7 \pm 0.30$ & $6.93 \pm 0.12$ & $3.90 \pm 0.14$ & $7.28 \pm 0.11$ & $2.51 \pm 0.15$ \\
\hline Cow dung + MSW (2:1) & $684.5 \pm 1.25$ & $13.5 \pm 0.23$ & $50.5 \pm 0.32$ & $7.11 \pm 0.11$ & $7.25 \pm 0.12$ & $7.39 \pm 0.15$ & $1.79 \pm 0.10$ \\
\hline Buffalo dung (control) & $519.8 \pm 1.51$ & $7.01 \pm 0.12$ & $74.0 \pm 0.37$ & $6.93 \pm 0.12$ & $5.25 \pm 0.13$ & $7.50 \pm 0.18$ & $1.71 \pm 0.11$ \\
\hline Buffalo dung + MSW (1:1) & $651.8 \pm 1.40$ & $14.5 \pm 0.16$ & $45.7 \pm 0.30$ & $8.21 \pm 0.15$ & $7.71 \pm 0.18$ & $7.77 \pm 0.15$ & $2.51 \pm 0.13$ \\
\hline Buffalo dung + MSW (1:2) & $687.7 \pm 1.35$ & $13.2 \pm 0.21$ & $74.4 \pm 0.26$ & $7.80 \pm 0.17$ & $5.41 \pm 0.15$ & $7.62 \pm 0.14$ & $1.98 \pm 0.15$ \\
\hline Buffalo dung + MSW $(2: 1)$ & $734.3 \pm 1.33$ & $13.9 \pm 0.22$ & $52.5 \pm 0.31$ & $8.82 \pm 0.15$ & $8.90 \pm 0.23$ & $7.91 \pm 0.18$ & $1.79 \pm 0.12$ \\
\hline Goat dung (control) & $433.0 \pm 1.06$ & $5.01 \pm 0.21$ & $86.3 \pm 0.37$ & $6.41 \pm 0.15$ & $4.21 \pm 0.13$ & $7.45 \pm 0.12$ & $2.81 \pm 0.22$ \\
\hline Goat dung + MSW (1:1) & $560.3 \pm 1.54$ & $13.2 \pm 0.20$ & $41.6 \pm 0.32$ & $7.29 \pm 0.24$ & $5.80 \pm 0.17$ & $7.77 \pm 0.15$ & $1.81 \pm 0.11$ \\
\hline $\mathrm{g}+\mathrm{MSW}(1: 2)$ & $3 \pm 1.33$ & $9.30 \pm 0.15$ & $63.9 \pm 0.35$ & $6.93 \pm 0.12$ & $4.71 \pm 0.21$ & $7.55 \pm 0.16$ & $2.39 \pm 0.17$ \\
\hline $\mathrm{g}+\mathrm{MSW}(2: 1)$ & $604.5 \pm 1.25$ & $13.0 \pm 0.14$ & $46.6 \pm 0.39$ & $8.78 \pm 0.13$ & $8.21 \pm 0.15$ & $7.81 \pm 0.19$ & $1.73 \pm 0.13$ \\
\hline Horse & 473 & \pm 0.49 & $94.3 \pm$ & $1 \pm 0.15$ & \pm 0.21 & $7.62=$ & \pm 0.11 \\
\hline Horse dung $+\mathrm{N}$ & $630.8 \pm 1.16$ & $13.5 \pm 0.23$ & $46.6 \pm 0.37$ & $8.01 \pm 0.11$ & $8.91 \pm 0.24$ & $7.31 \pm 0.13$ & $1.83 \pm 0.21$ \\
\hline Horse dung + & 52 & 12 & 10 & \pm 0.21 & \pm 0.15 & 10 & \pm 0.15 \\
\hline Horse dung + MSW $(2: 1)$ & $719.8 \pm 1.51$ & $11.5 \pm 0.13$ & $62.7 \pm 0.33$ & $8.20 \pm 0.22$ & $11.3 \pm 0.25$ & $7.50 \pm 0.17$ & $1.72 \pm 0.19$ \\
\hline \multicolumn{8}{|l|}{ Final vermicompost } \\
\hline MSW & $197.5 \pm 0.72^{*}$ & $14.1 \pm 0.10^{*}$ & $14.4 \pm 0.14^{*}$ & $6.31 \pm 0.10^{*}$ & $6.13 \pm 0.10^{*}$ & $6.23 \pm 0.10^{*}$ & $\pm 0.10^{*}$ \\
\hline Cow dung (control) & $203.6 \pm 0.80^{*}$ & $16.2 \pm 0.11 *$ & $13.4 \pm 0.11^{*}$ & $5.89 \pm 0.10^{*}$ & $7.1 \pm 0.13 *$ & $13 *$ & $2.03 \pm 0.11 *$ \\
\hline Cow dung + MSW (1:1) & $264.5 \pm 0.76^{*}$ & $25.1 \pm 0.12 *$ & $10.4 \pm 0.10^{*}$ & $7.43 \pm 0.11^{*}$ & $7.46 \pm 0.10^{*}$ & $7.10 \pm 0.12 *$ & $2.81 \pm 0.18 *$ \\
\hline Cow dung + MSW (1:2) & $224.8 \pm 0.67 *$ & $18.4 \pm 0.13^{*}$ & $12.5 \pm 0.13^{*}$ & $7.13 \pm 0.10^{*}$ & $5.67 \pm 0.11^{*}$ & $7.15 \pm 0.11^{*}$ & $2.60 \pm 0.16^{*}$ \\
\hline Cow dung + MSW (2:1) & $307.3 \pm 0.66^{*}$ & $25.5 \pm 0.13^{*}$ & $12.1 \pm 0.14^{*}$ & $7.96 \pm 0.10^{*}$ & $9.88 \pm 0.16^{*}$ & $7.28 \pm 0.16^{*}$ & $2.71 \pm 0.21 *$ \\
\hline Buffalo dung (control) & $258.8 \pm 0.74^{*}$ & $11.4 \pm 0.10^{*}$ & $22.4 \pm 0.12 *$ & $7.35 \pm 0.10^{*}$ & $6.31 \pm 0.13 *$ & $7.21 \pm 0.13^{*}$ & $3.10 \pm 0.14^{*}$ \\
\hline Buffalo dung + MSW (1:1) & $323.6 \pm 0.88^{*}$ & $24.2 \pm 0.24 *$ & $13.1 \pm 0.10^{*}$ & $8.31 \pm 0.11^{*}$ & $7.71 \pm 0.12 *$ & $7.16 \pm 0.12 *$ & $4.70 \pm 0.15^{*}$ \\
\hline Buffalo dung + MSW (1:2) & $283.5 \pm 0.76^{*}$ & $18.3 \pm 0.11^{*}$ & $15.4 \pm 0.14^{*}$ & $8.33 \pm 0.11^{*}$ & $5.90 \pm 0.13^{*}$ & $7.30 \pm 0.13^{*}$ & $4.49 \pm 0.16^{*}$ \\
\hline Buffalo dung + MSW $(2: 1)$ & $394.8 \pm 0.60^{*}$ & $23.4 \pm 0.11 *$ & $16.9 \pm 0.11^{*}$ & $8.40 \pm 0.14 *$ & $10.8 \pm 0.15^{*}$ & $7.71 \pm 0.13^{*}$ & $4.90 \pm 0.17 *$ \\
\hline Goat dung (control) & $234.5 \pm 0.76^{*}$ & $10.4 \pm 0.10^{*}$ & $22.9 \pm 0.10^{*}$ & $6.93 \pm 0.11^{*}$ & $5.38 \pm 0.19 *$ & $7.06 \pm 0.19^{*}$ & $2.91 \pm 0.21 *$ \\
\hline Goat dung + MSW (1:1) & $302.5 \pm 0.76^{*}$ & $25.4 \pm 0.11^{*}$ & $12.0 \pm 0.11^{*}$ & $8.88 \pm 0.14^{*}$ & $7.20 \pm 0.15^{*}$ & $7.40 \pm 0.15^{*}$ & $3.70 \pm 0.15^{*}$ \\
\hline Goat dung +MSW (1:2) & $256.6 \pm 0.71^{*}$ & $19.3 \pm 0.10^{*}$ & $13.3 \pm 0.11^{*}$ & $7.36 \pm 0.12^{*}$ & $5.24 \pm 0.17 *$ & $7.24 \pm 0.17^{*}$ & $3.90 \pm 0.11 *$ \\
\hline Goat dung + MSW (2:1) & $366.8 \pm 0.47^{*}$ & $27.2 \pm 0.24 *$ & $13.4 \pm 0.14^{*}$ & $8.81 \pm 0.15^{*}$ & $8.51 \pm 0.19^{*}$ & $7.51 \pm 0.19^{*}$ & $5.35 \pm 0.12 *$ \\
\hline Horse dung (control) & $216.1 \pm 0.47^{*}$ & $8.51 \pm 0.11^{*}$ & $25.2 \pm 0.47$ & $8.51 \pm 0.13^{*}$ & $10.2 \pm 0.21 *$ & $7.31 \pm 0.14^{*}$ & $4.11 \pm 0.21 *$ \\
\hline Horse dung + MSW (1:1) & $255.0 \pm 0.57^{*}$ & $22.7 \pm 0.10^{*}$ & $11.7 \pm 0.11^{*}$ & $8.10 \pm 0.12^{*}$ & $10.5 \pm 0.15^{*}$ & $7.10 \pm 0.16^{*}$ & $5.99 \pm 0.17 *$ \\
\hline Horse dung + MSW (1:2) & $203.5 \pm 0.66^{*}$ & $17.2 \pm 0.25^{*}$ & $11.9 \pm 0.14^{*}$ & $8.61 \pm 0.16^{*}$ & $8.21 \pm 0.19^{*}$ & $6.80 \pm 0.19^{*}$ & $3.32 \pm 0.21 *$ \\
\hline Horse dung + MSW $(2: 1)$ & $353.1 \pm 0.61 *$ & $23.5 \pm 0.19^{*}$ & $15.3 \pm 0.17 *$ & $8.16 \pm 0.19^{*}$ & $13.4 \pm 0.21 *$ & $7.30 \pm 0.21 *$ & $6.10 \pm 0.23 *$ \\
\hline
\end{tabular}

Each value is the mean \pm SD of six replicate. $M S W$ municipal solid wastes

* Significant combinations $(p<0.05)$ determined by two-way analysis of variance (ANOVA) was applied in between the different paramagnet of vermiwash of initial feed mixture and final vermiwash 
Fig. 1 The TOC (total organic carbon) concentration in vermiwash of different combinations of animal dung with MSW (municipal solid wastes). IFM Initial feed mixture before vermicomposting, $F V W$ final vermiwash after

Vermicomposting

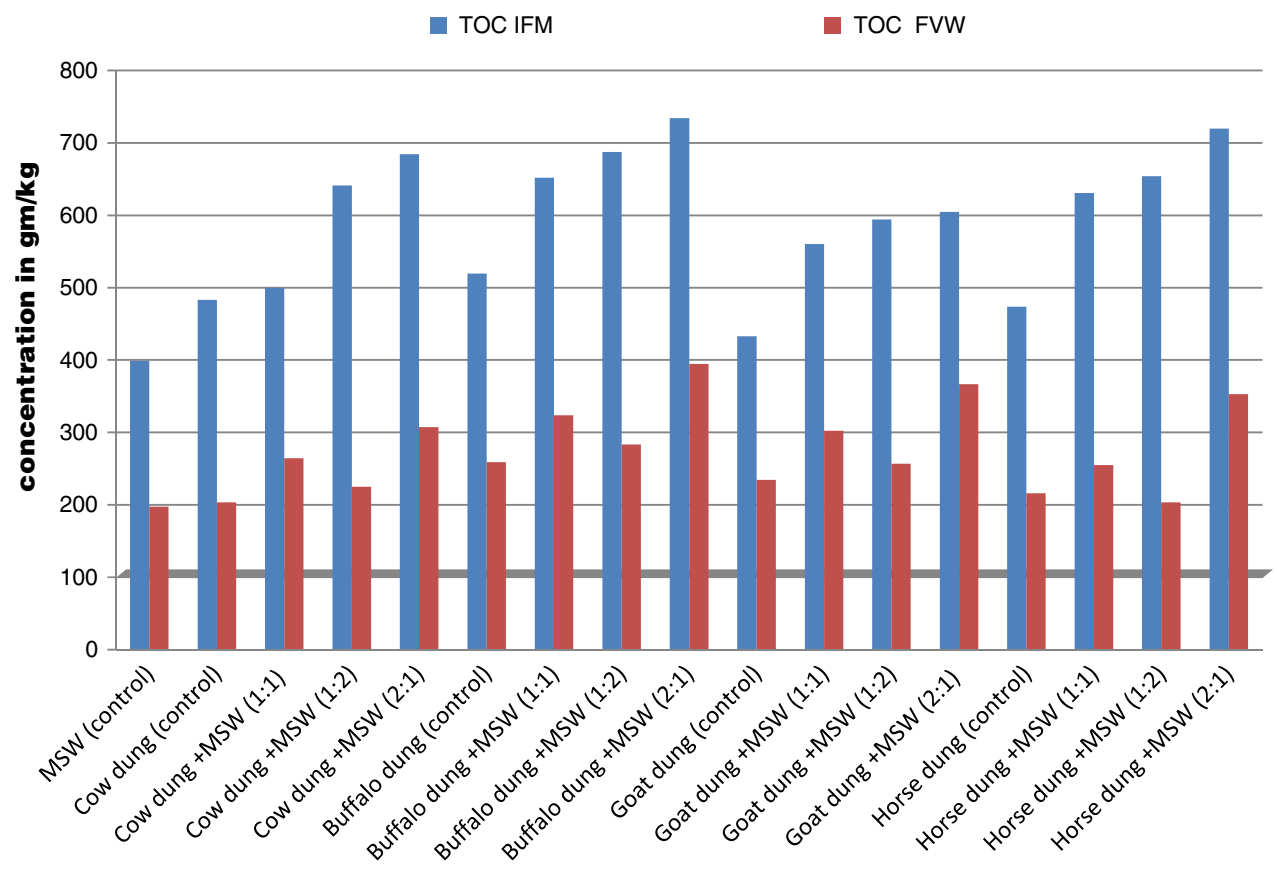

Different combination of animal dung with MSW significant increase level of TKN $(27.2 \pm 0.24 \mathrm{~g} / \mathrm{kg})$ in goat dung + MSW (2:1 ratio), TK $(8.81 \pm 0.15 \mathrm{~g} / \mathrm{kg})$ in the goat dung + MSW (1:1 ratio), TP $(13.4 \pm 0.21 \mathrm{~g} / \mathrm{kg})$ in horse dung $+\operatorname{MSW}(2: 1$ ratio) were observed in the vermiwash of final vermicompost. The maximum concentration of $\mathrm{TCa}$ was $6.10 \pm 0.23 \mathrm{~g} / \mathrm{kg}$ in the combination of horse dung + MSW (2:1 ratio). The increased level of TCa ranged from 30 to $80 \%$ in final vermicompost with respect to initial feed mixture of all the combinations of MSW with animal dung (Figs. 1, 2, 3).

\section{Discussion}

The vermiwash of final vermicompost shows significant changes in different physico-chemical properties, when different animal dungs were mixed with MSW. This is because that the vermicomposting increases the beneficial soil microflora, destroys the pathogen of soil and converts organic wastes into valuable products (Suthar 2007). During the vermicomposting, important nutrients such as N, P, $\mathrm{K}$, and $\mathrm{Ca}$ present in the feed material are converted into much soluble nutrients through earthworm action which are now easily usable for plants (Payal et al. 2006). Earthworms also play an important role in stabilization of inorganic plant nutrients to organic form and increase the soil fertility. Further the worms add their cast with compost and increase the inorganic nutrients many times along with some plant growth hormones and vitamins (Ranganathan 2006). The vermicomposting process also increases the mineralization rate. When organic wastes pass through the gut of worm, the nutrients get converted from unavailable form to available forms, which consequently enrich the worm cast with higher quality plant nutrient (Gupta and Garg 2008).

In the final vermiwash of horse dung + MSW (1:2 ratio), a significant decrease in TOC was observed, it may be due to the presence of high amount of organic compound in MSW (Kaviraj and Sharma 2003) and due to the feeding action of earthworm and degradation by microbes in the intestine of earthworm which loses the carbon in the form of $\mathrm{CO}_{2}$ as well as utilized the carbon for energy production in metabolism (Suthar 2007). The results also illustrate that $\mathrm{C} / \mathrm{N}$ ratio decreases in the combination of cow dung + MSW (1:1 ratio). This is because of the fact that microbial decomposition is one of the major factors that caused a significant decrease in the $\mathrm{C} / \mathrm{N}$ ratio (Nath and Singh 2009; Chauhan and Singh 2012a, b). Addition of cow dung as palatable waste results in the reduction of $\mathrm{C} / \mathrm{N}$ ratio, and influencing vermicomposting rate by increasing certain macronutrients in vermicompost (Muthukumaravel et al. 2008). Muthukumaravel et al. (2008) observed that the mixture of vegetable wastes and cow dung is suitable for the production of high quality of vermicomposts with respect to their individual component. The maximum decrease in $\mathrm{pH}$ level was observed in the combination of buffalo dung + MSW (1:1 ratio). The shifting of $\mathrm{pH}$ from base to acidic or neutral condition was due to mineralization of nitrogen into nitrate/nitrite and phosphate into orthophosphate (Garg et al. 2006). Degradation in the level of $\mathrm{pH}$ is an important factor in increasing the quality of 
Fig. 2 The concentration of TK (total potassium), TKN (total Kjeldahl nitrogen) and $\mathrm{C} / \mathrm{N}$ ratio in vermiwash of different combinations of animal dung with MSW (municipal solid wastes). IFM Initial feed mixture before

vermicomposting, $F V W$ final vermiwash after vermicomposting
Fig. 3 The concentration of TCa (total calcium), TP (total potassium) and $\mathrm{pH}$ in vermiwash of different combinations of animal dung with MSW (municipal solid wastes). IFM Initial feed mix

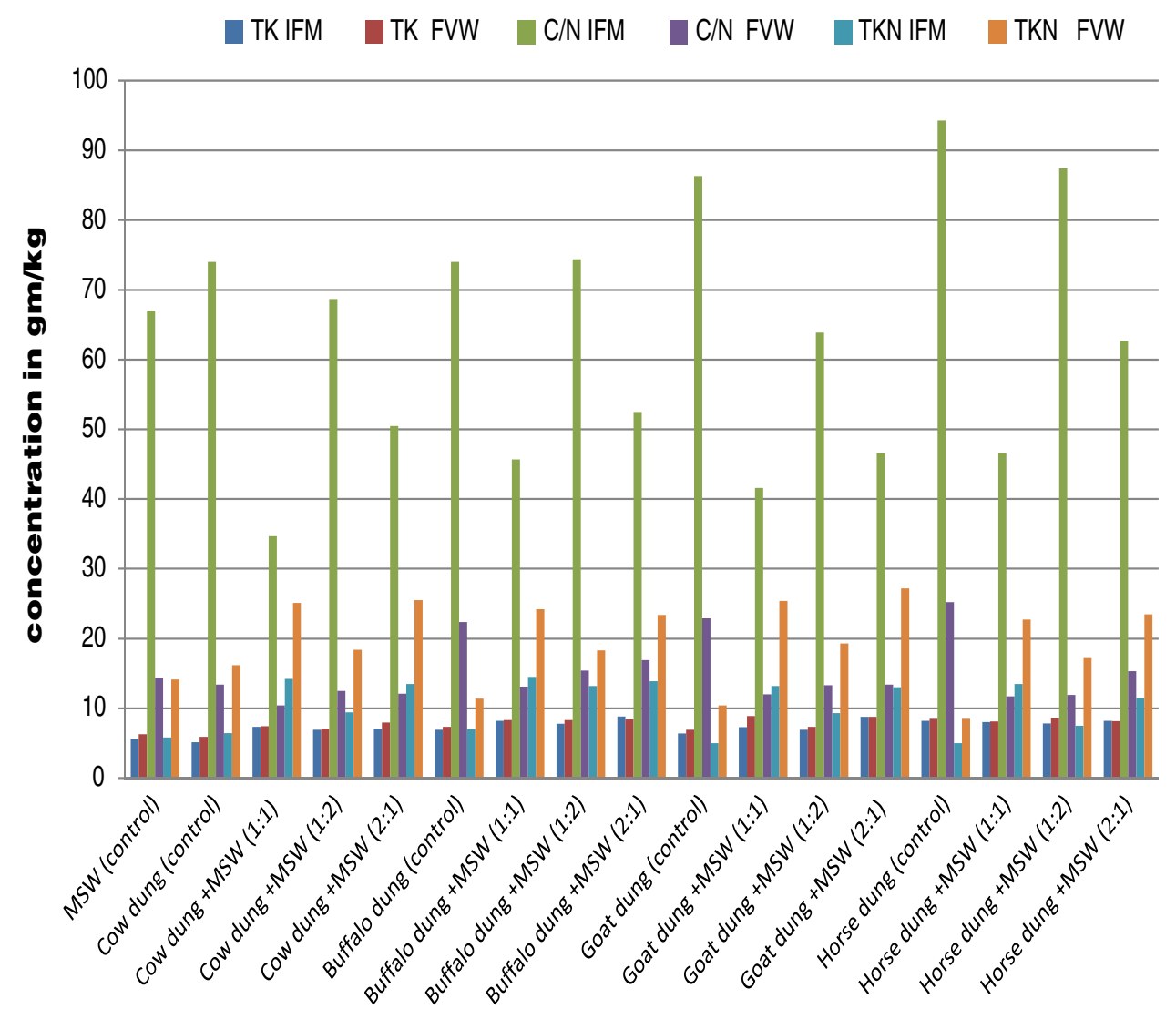

Different combination of animal dung with MSW

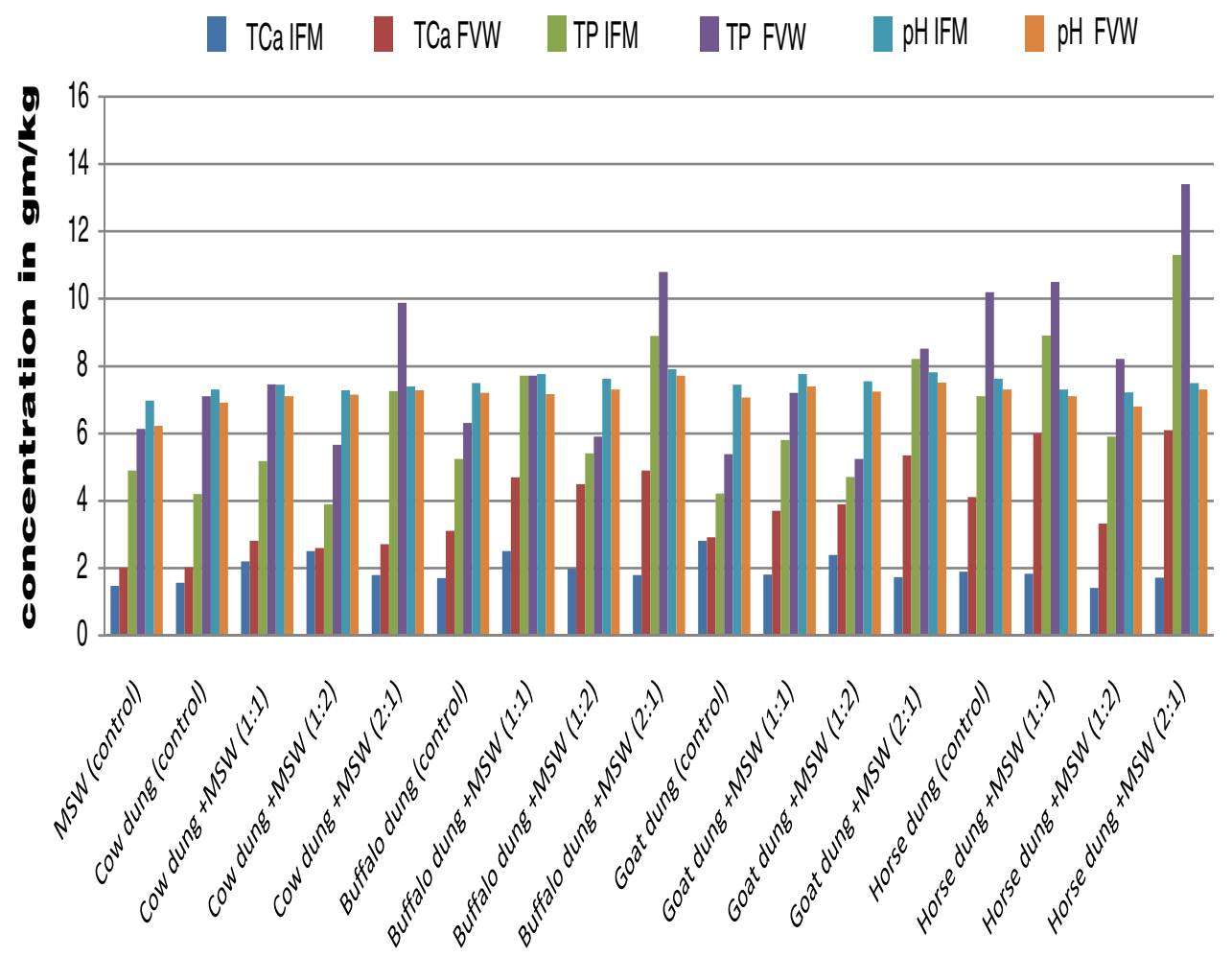

Different combination of animal dung with MSW 
fertilizer because at higher $\mathrm{pH}$ nitrogen is lost in the form of volatile $\mathrm{NH}_{3}$ (Nath and Singh 2009). During vermicomposting, the decrease in $\mathrm{pH}$ is also likely due to production of $\mathrm{CO}_{2}$, ammonia and organic acid by microorganism activity (Sharma et al. 2011).

There was maximum significant increase in the level of TKN in goat dung + MSW, it may be due to degradation of organic carbon and addition of some gut products in the form of castings, urine and dead tissues of the earthworm (Tripathi and Bharadwaj 2004). The highest significant TP was observed in horse dung + MSW (2:1) combination which was probably because of the solubilization and stabilization of phosphorous done by microorganism present in earthworm gut; the phosphatase enzyme also increases the total phosphorous after vermicomposting (Aira et al. 2002, Suthar et al. 2008). The results show significant increase in the level of total potassium (TK) in the combination of goat dung + MSW. Further the microorganisms during vermicomposting produce some amino acids which convert the insoluble K into soluble form. Kaviraj and Sharma (2003) have noticed 10 and $5 \%$ increased TK level during vermicomposting by E. fetida and Lampito mauritii, respectively. In the present investigation, the maximum concentration of TCa was $6.10 \pm 0.23 \mathrm{~g} / \mathrm{kg}$ in the combination of horse dung + MSW (2:1 ratio). The increased level of TCa ranged from 30 to $80 \%$ in final vermicompost with respect to initial feed mixture of all the combinations of MSW in animal dung. It is possible that gut process associated with $\mathrm{Ca}^{2+}$ metabolism is primarily responsible for enhancement in the content of inorganic $\mathrm{Ca}^{2+}$ in worm cast. Highest $\mathrm{Ca}^{2+}$ level was noticed in combination of buffalo dung + rice bran which is due to the higher rate of $\mathrm{Ca}^{2+}$ mineralization (Garg et al. 2006; Suthar et al. 2008). Total calcium was observed significantly highest in all the final vermicomposts, which may be due to the process of stabilization in which the unavailable form is changed into available form of TCa during vermicomposting (Nath and Singh 2009; Chauhan and Singh 2012a, b).

The nature and composition of the agro-industrial wastes and animal dung ultimately influence the level of nutrients present in the vermicompost. Agro-industrial wastes are the excellent source of nutrient. The vermicomposts of agroindustrial wastes have higher level of micro and macronutrients than initial feed mixture. The waste materials ingested by the earthworm are supposed to undergo biochemical changes leading to the mixing of plant nutrient and growth promoting substances in an assimilated form.

\section{Conclusion}

It can be concluded from this study, that the vermiwash obtained from vermicompost of different animal dungs with MSW shows significant increase in the levels of TKN, TK, TP, TCa and decrease in the levels of TOC, C/N and $\mathrm{pH}$. These physico-chemical changes improved the quality of soil. Thus, vermicomposting can be a better technology for the conversion of toxic health hazardous wastes into valuable products. Vermicomposting also proved to be helpful in the bio-management of MSW. Vermicomposting is less expensive, non-hazardous and eco-friendly for human as well as animal health. The specific nutrient-rich vermicompost of the particular combination of the animal and MSW can be helpful in maintaining the texture of specific nutrient-deficient soil.

Open Access This article is distributed under the terms of the Creative Commons Attribution License which permits any use, distribution, and reproduction in any medium, provided the original author(s) and the source are credited.

\section{References}

Aalok A, Tripathi AK, Soni P (2008) Vermicomposting: a better option for organic solid waste management. J Hum Ecol 24(1):59-64

Aira M, Monroy F, Domínguez J, Mato S (2002) How earthworm density affect microbial biomass and activity in pig manure. Eurasian J Soil Biol 38:7-10

Astaraei AR, Ivani R (2008) Effect of organic sources as foliar spray and root media on Cow pea plant. Am Eurasian Environ Sci 3(3):352-356

Bhartiya DK, Singh K (2012) Heavy metals accumulation from municipal solid wastes with different animal dung through vermicomposting by earthworm Eisenia fetida. World Appl Sci J 17(1):133-139

Bremner JM, Mulvaney RG (1982) Nitrogen total in method of soil analysis. In: Page AL, Millar RH, Keeney DR (eds) American Society of agronomy, Madison, pp 575-624

Chauhan HK, Singh K (2012a) Effect of binary combinations of buffalo, cow and goat dung with different agro wastes on reproduction and development of earthworm Eisenia fetida (Haplotaxida: Lumbricidae). World J Zool 7:23-29

Chauhan HK, Singh K (2012b) Effect of different binary combinations of biological wastes on the reproduction and development of earthworm Eisenia fetida. Int $\mathrm{J}$ Environ Sci Eng Sci $3(2): 22-31$

Garg VK, Kaushik P (2003) Vermicomposting of solid textile will sludge and cow dung with the epigeic earthworm Eisenia fetida. Bioresour Technol 90:311-316

Garg VK, Chand S, Chhillar A, Yadav VK (2005) Growth and reproduction of Eisenia fetida in various animal wastes during vermicomposting. Appl Ecol Environ Res 3(2):51-59 Hungary

Garg VK, Yadav YK, Sheoran A, Chand S, Kaushik P (2006) Live stocks excreta management through vermicomposting using an epigeic earthworm Eisenia fetida. Environmentalist 26:269-276

Gupta R, Garg VK (2008) Stabilization of primary sewage sludge during vermicomposting. J Hazard Mater 153(3):1023-1030

Kaviraj, Sharma S (2003) Municipal solid wastes management through vermicomposting employing exotic and local species of earthworm. Bioresour Technol 90:169-173

Muthukumaravel K, Amsath A, Sukumaran M (2008) Vermicomposting of vegetable wastes using cow dung. Environ J Chem 5(4):810-813 
Nath G, Singh K, Singh DK (2009) Chemical analysis of vermicomposts/vermiwash of different combinations of animal, agro and kitchen wastes. Aust J Basic Appl Sci 3(4):3672-3676

Nelson DW, Sommers LE (1982) Total carbon and organic carbon matter. In: Page AL, Miller RH, Keeney DR (eds) Method of Soil Analysis. American Society of Agronomy, Madison, pp 539-579

Payal G, Gupta A, Satya S (2006) Vermicomposting of different types of wastes using Eisenia fetida a comparative study. Bioresour Technol 97:391-395

Ranganathan LS (2006) Vermibiotechnology from soil health to human health. Agrobios, India

Rouse JR, Rothemberger S, Zurbrugg C (2008) Marketing compost. A guide for compost producer in low and middle income countries. SANDEC, Swiss Federal Institute of aquatic Science and Technology (EAWAG), Switzerland
Sharma D, Katnoria JK, Vig AP (2011) Chemical changes of spinach waste during composting and vermicomposting. Afr J Biotechnol 10:3124-3127

Suthar S (2007) Nutrient changes and biodynamics of epigeic earthworm Perionyx excavatus (Perrier) during recycling of some agriculture wastes. Bioresour Technol 98:1608-1614

Suthar S, Singh S, Dhawan S (2008) Earthworm as bioindicators of metals $(\mathrm{Zn}, \mathrm{Fe}, \mathrm{Mn}, \mathrm{Cu}, \mathrm{Pb}$ and $\mathrm{Cd})$ in soils: is metal bioaccumulation affected by their ecological categories. Ecol Eng 32:99-107

Tripathi G, Bharadwaj P (2004) Comparative studies on biomass production, life cycles and composting efficacy of Eisenia fetida (Savigny) and Lampito mauritii (Kinberg). Bioresour Technol 92(3):275-283 